\title{
LEGAL BARRIERS AND QUALITY COMPLIANCE IN THE BUSINESS OF BIOFERTILIZERS AND BIOPESTICIDES IN INDIA
}

\author{
Hasrat Arjjumend \\ Faculté de droit, Université de Montréal; CISDL, McGill University Faculty of Law, Montreal \\ (Quebec), Canada,E-mail: hasrat.arjjumend@umontreal.ca
}

\section{Konstantia Koutouki}

Faculté de droit, Université de Montréal; CISDL, McGill University Faculty of Law, Montreal (Quebec), Canada, E-mail: konstantia.koutouki@umontreal.ca

\section{(Received: September 2020; Accepted: October 2020; Published: November 2020)}

\begin{abstract}
Biofertilizers and biopesticides (together known as 'biologicals') hold the potential to increase farmers' current agricultural productivity, while at the same time contributing to the soil's ability to produce more in the future. However, the legal registration of microbial products and the operation of businesses dealing in biologicals face certain barriers, which ultimately affect the expansion and widespread use of these green products in Indian agriculture. By involving manufacturers, suppliers and traders of biologicals, as well as government officers dealing with biologicals in India, a study was conducted using participatory methods of semi-structured interviews, structured interviews and informal discussions. This article explores the participants' perceptions and understanding of the barriers, obstacles and issues in the registration, licensing, proliferation and business operations surrounding the manufacturing, sale, trade, import, export, storage, use, and transport of microbial products. Numerous barriers to business and trade in microbial green products - biofertilizers and biopesticides - are identified. Nevertheless, certain weaknesses related to quality compliance and monitoring are also identified on the part of the manufacturers and suppliers of these biologicals, indicating that the government's regulatory system must be more efficient and competent in handling these processes.
\end{abstract}

Keywords: Registration barrier, Biopesticides, Biofertilizers, License, Quality monitoring, Effectiveness.

\section{Introduction}

In an effort to obtain higher crop yields and food production, the use of unsustainable levels of chemical fertilizers and plant protection chemicals has

\footnotetext{
${ }^{*}$ Corresponding author: Hasrat Arjjumend. E-mail: hasrat.arjjumend@umontreal.ca.
} reproduction in any medium, provided the original author and source are credited. 
Arjjumend, H., Koutouki. K., (2020)

Legal barriers and quality compliance in the business of biofertilizers and biopesticides in India

resulted in a steady decline in soil and crop productivity the world over. Investing in sustainable agriculture is one of the most effective ways to simultaneously achieve the sustainable development goals (SDGs) related to poverty and hunger, nutrition and health, education, economic and social growth, peace and security, and the preservation of the world's environment (Earth Alive, 2017). Biofertilizers and biopesticides (together known as 'biologicals') hold the potential to increase farmers' current agricultural productivity, while at the same time contributing to the soil's ability to produce more in the future. However, the legal registration of microbial products and the operation of businesses dealing in biologicals face certain barriers, which ultimately affect the expansion and widespread use of these green products in Indian agriculture.

Biofertilizers in India came under legal regulation in March 2006. In addition, with the Gazette Notification of 3 November 2009, the Ministry of Agriculture further amended the Essential Commodities Act, 1955 and the Fertilizer (Control) Order, 1985 to accommodate the regulation of biofertilizers and organic fertilizers. Manufacturers, sellers, importers, or traders are required to register under the Fertilizers (Control) Amendment Order 2003 before selling biofertilizers that originate from Rhizobium, Azotobacter, Azospirillum, phosphate solubilizing bacteria, and mycorrhizal biofertilizers. At the time of application for registration, these products must be tested by an authorized government laboratory. Similarly, the Insecticides Act, 1968 and Insecticides Rules, 1971 regulate the import, registration process, manufacture, sale, transport, distribution and use of insecticides (pesticides) with a view to preventing risk to human beings or animals and for all connected matters. However, recently the Union Cabinet gave its approval for the introduction of the Pesticides Management Bill, which would replace the existing Insecticide Act, 1968. Pesticide regulations in India are governed by two different bodies: the Central Insecticides Board and Registration Committee (CIBRC) and the Food Safety and Standards Authority of India (FSSAI). CIBRC is responsible for advising central and state governments on technical issues related to the manufacture, use and safety of pesticides (Bhide, 2013). The Department of Biotechnology of the Ministry of Science \& Technology plays the role of technical agency in the approval process for effectiveness, quality and safety issues. In addition to these regulations, organic food producers in India are supposed to comply with the National Program for Organic Production (NPOP) standards with mandatory organic certification by authorized certification agencies. In the present study, two groups of participants - manufacturers, suppliers and traders of biologicals, and government officers dealing with biologicals - were interviewed between April 2018 and March 2019 using semi-structured interviews, structured interviews, informal discussions, and observation. Several variables, including the biological relevance and effectiveness of microbial products, barriers 
Arjjumend, H., Koutouki. K., (2020)

Legal barriers and quality compliance in the business of biofertilizers and biopesticides in India

to business and registration, and the efficacy and efficiency of monitoring, were studied. This article explores participants' perceptions and understanding of participant barriers, obstacles and issues in the registration, licensing, proliferation and business operations surrounding the manufacturing, sale, trade, import, export, storage, use, and transport of microbial products. This article is part of a larger study conducted between September 2017 and February 2020 by the authors at the Faculty of Law, Université de Montréal, with the support of Mitacs and Earth Alive Clean Technologies.

\section{Methodology}

This research was conducted in India in order to understand barriers to business and the registration of biologicals, as well as the efficacy and efficiency of monitoring. In addition to primary data obtained by interviewing participant groups, pertinent literature was also reviewed.

\subsection{Sampling and Sample Techniques}

Two participant groups were chosen to conduct the study: Group 1 - Manufacturers and Suppliers (G.1); and Group 2 - Government Officers (G.2). The Group 1 participants (as listed in Appendix 1) are direct stakeholders who provided insights on registration-related barriers to the proliferation and promotion of biologicals and have been affected by the regulatory barriers to biofertilizers and biopesticides. They also responded to questions concerning the monitoring of the quality, efficiency and efficacy of biologicals. Group 2 participants (as listed in Appendix 2) are involved in policy development, legal implementation, and enforcement issues concerning biologicals. Some of the information provided by these participants was shared in an informal manner, as they are not permitted to share such information formally, or in writing. Table 1 contains the total sample size of each of the participant groups. Following the pre-appointments through phone or email, participants were visited and interviewed in person.

For the data augmentation from each participant group, different sampling techniques were used, as indicated in Table 1 (below). Group 1 participants were sampled using purposive sampling and snowball sampling techniques. Group 2 participants were sampled using purposive sampling and expert sampling. 
Arjjumend, H., Koutouki. K., (2020)

Legal barriers and quality compliance in the business of biofertilizers and biopesticides in India

\begin{tabular}{|c|c|c|c|c|}
\hline \multicolumn{5}{|c|}{ Table 1} \\
\hline $\begin{array}{l}\text { Participant } \\
\text { Group }\end{array}$ & $\begin{array}{c}\text { Sample } \\
\text { Size }\end{array}$ & Names of States & $\begin{array}{l}\text { Sampling } \\
\text { Method }\end{array}$ & Research Method \\
\hline $\begin{array}{l}\text { G.1 } \\
\text { Manufacturers } \\
\text { and Suppliers }\end{array}$ & 8 & $\begin{array}{l}\text { West Bengal, } \\
\text { Punjab, Haryana }\end{array}$ & $\begin{array}{l}\text { Snowball, } \\
\text { Purposive } \\
\text { sampling }\end{array}$ & $\begin{array}{l}\text { Semi-structured } \\
\text { interview; Structured } \\
\text { interview }\end{array}$ \\
\hline $\begin{array}{l}\text { G.2 } \\
\text { Government } \\
\text { Officers }\end{array}$ & 8 & $\begin{array}{l}\text { Uttarakhand, } \\
\text { Haryana, West } \\
\text { Bengal, Uttar } \\
\text { Pradesh, Delhi }\end{array}$ & $\begin{array}{l}\text { Purposive } \\
\text { sampling, } \\
\text { Expert } \\
\text { sampling }\end{array}$ & $\begin{array}{l}\text { Informal discussion; } \\
\text { Semi-structured } \\
\text { interview }\end{array}$ \\
\hline
\end{tabular}

Source: Self-research

\subsection{Methods of Data Collection}

Participants of Group 1 responded to the questions listed in Table 2. The data gathering methods used were semi-structured and structured interviews (Table 1). Participants of Group 2 were surveyed through semi-structured interview and informal discussion methods (Table 1). The questions for these participants are listed in Appendix 3.

\subsection{Certificat d'approbation d'éthique (Ethical Approval Certificate) and its Compliance}

The Multi-Faculty Committee on Research Ethics (Comité plurifacultaire d'éthique de la recherche - CPER) of the Université de Montréal issued an Ethical Approval Certificate (no. CPER-17-114-P) to the study project. During the collection of field data from two participant groups, the conditions of the Ethics Certificate were met. A consent form was presented to each of the individual participants either in English or Hindi, depending on participant preference. This form was signed by both the participant and the field researcher. Before any discussion or interview with a participant took place, each individual was informed of the research objectives through an information sheet describing the role of the participant, the benefits of sharing information, measures concerning confidentiality, and the participant's right to withdraw from the study. Free and prior informed consent was then obtained from each participant.

\section{Results and Discussion}

The present article explores the legal and procedural barriers to the agricultural biological industry in India, including with respect to trials, storage, transport, sale, trade, import, manufacturing and exhibition of microbial biofertilizers and biocontrol agents, based on an analysis of the responses given by surveyed manufacturers/suppliers and government officers. It also examines the technical 
Arjjumend, H., Koutouki. K., (2020)

Legal barriers and quality compliance in the business of biofertilizers and biopesticides in India

effectiveness of microbial products and the quality of monitoring by producers and concerned government officials.

\subsection{Types of Biologicals and their Effectiveness}

The manufacturers and suppliers surveyed identified the following categories of biofertilizers in India (also see Table 2):

i. Rhizobium.

ii. Azotobacter.

iii. Acetobacter.

iv. Azospirillum.

v. Mycorrhiza.

vi. Phosphate Solubilizing Bacteria (PSB).

vii. Potash Solubilizing Bacteria (KSB).

viii. Zinc Solubilizing Bacteria (ZSB).

ix. Consortia.

x. Plant Growth Regulators.

xi. Enzymes.

xii. Plant Tonic.

xiii. Sulphur-Iron Solubilizer.

With respect to the efficacy of such biofertilizers, the participants of Group 1 observed that the use of Azotobacter resulted in yield increases of $20-70 \%$ for maize, wheat and rice crops, and yield increases of $22-30 \%$ for vegetables (Table 2). Several of the Group 1 participants also stated that the use of biofertilizers increased germination by $20-30 \%$, and saved on the usage of nitrogen by $25-30 \%$ (Table 2). Other Group 1 participants stated that the application of nitrogen could be reduced to $50 \%$ if biofertilizers were used. None of the manufacturers/suppliers surveyed shared laboratory test data on the efficacy of their products, with some stating that efficacy data are not required for biofertilizers. Yet, according to the participant government officers, some data such as the CFU count [1] is in fact required, and must be collected, analyzed and presented to the registration office.

The Group 1 participants surveyed also identified the categories of existing biopesticides manufactured or supplied/traded in the country (Table 2), which are as follows:

a) Biofungicides (e.g. Trichoderma viride, Pseudomonas fluorescence).

b) Biopesticides.

c) Bioinsecticides (e.g. Bacillus thuringiensis).

d) Bionematicide (e.g. Verticillium chlamydosporium).

The same Group 1 participants shared their opinion concerning testing to determine the efficacy of their products (Table 2). According to them, tests are conducted by 
Arjjumend, H., Koutouki. K., (2020)

Legal barriers and quality compliance in the business of biofertilizers and biopesticides in India

the Central Insecticides Board (CIB) labs at the time of the registration process (Table 2). None of the participants shared any laboratory data they have acquired, although they stated that biopesticides do require biosafety data at the time of registration (Table 2).

\subsection{Barriers in the Registration and Certification Process}

Group 1 participants surveyed brought attention to the procedures for the registration, manufacturing, import, trade/sale, transport, storage, and disposal of biofertilizers and biopesticides (Table 2). The registration application for biopesticides is submitted to the Central Insecticides Board (CIB) at the Ministry of Agriculture and registration is undertaken under the Insecticides Act 1968. The selling licenses for biopesticides are issued by the state governments. However, registering a biopesticide is a very hard and expensive process.

On the other hand, biofertilizers are registered with the Agriculture Department of a state government under the Fertilizer Control Order 1985 (FCO), which also issues licenses for their manufacture, import, trade, transport, and storage (Table 2). For biofertilizers, a selling or distribution license is issued at the district level by the District Agriculture Department. Although the stipulated time period in FCO and Insecticides Rules is 30 days from the date of application, the registration under FCO consumes half a year, and it takes nearly 18 months to register a new biopesticide (Table 2). Thus, although the manufacturing of biofertilizers in India is relatively easy and advantageous, compared to the lengthy procedure for importing.

What kind of laboratory tests or efficacy tests are required for biologicals? This question was answered by the manufacturers/suppliers (Table 2) and government officials. A great deal of scientific data is required to register biopesticides, including data on toxicity, HPLC [2], hortitoxicity, efficacy, and bioefficacy. For biofertilizers, efficacy tests on the crops (how microbial agents boost plant growth) are not required at the time of registration. Samples of biofertilizers are taken later for laboratory testing to determine properties such as CFU count and the sieve size of microbial agents. For biopesticides, which require meticulous tests and analyses, efficacy tests and bioassays are typically carried out at the research sites of designated universities or institutes (Table 2).

The participants also described the documents, preparations, facilities, and compliance measures required to apply for registration. They stated that an applicant for registration should possess a qualification in agriculture or science. Moreover, application forms require product's certificate of origin, test reports, microbiological performances, bioassays, toxicity reports, manufacturing process details, efficiency reports, company registration, tax-related registrations, 
Arjjumend, H., Koutouki. K., (2020)

Legal barriers and quality compliance in the business of biofertilizers and biopesticides in India

declarations, warehouse and storage details, and several other similar documents (Table 2).

Group 1 participants gave opinions about barriers at each step of the registration process (Table 2). They stated that it is difficult to register a new product, especially a biopesticide. Only some biopesticides are recognized and approved. Registration for an industrial dealer or retailer license is done separately in each state, meaning that multiple registrations are required in order to sell these products in different states (Table 2). Other issues include a lack of proper information and guidance. Government departments do not provide adequate help and assistance, and the callous attitude of officers and their lack of cooperation were cited as common problems (Table 2). Other bottlenecks include no synchronized system of facilitation, lengthy procedures, poor departmental coordination, no fixed responsibility, no clarity in procedures and types of documents, poor competence of the officers, lack of legal knowledge, and standards that are difficult to comply with (Table 2). Officers also do not ask for all required information at one time, causing hardships and delays in the process (Table 2). Concerning state-level registration and district-level licenses, the Group 2 participants stated that technical specifications for bacteria or fungi are very stringent and that licenses are valid for one state only. According to Group 1 participants, when no data exists on traded biofertilizers and biopesticides in different states, a tremendous amount of data is required to register biopesticides and biofertilizers (Table 2). The registration cost for biopesticides is another important barrier. The costs involved in all steps of the registration process and associated preparations and compliance measures for a biopesticide amount to approximately INR 6000,000 (Table 2). Some participants suggested that INR 100,000 is spent on registering a biopesticide, and a small company cannot afford such a large cost (Table 2 ).

Table 2: Manufacturers, suppliers, importers and traders of microbial biofertilizers and biopesticides

\begin{tabular}{|l|l|}
\hline \multicolumn{2}{|c|}{\begin{tabular}{c} 
Questions \\
\multicolumn{1}{|c|}{ Respontification and Characterization of Barriers } \\
in Registration and Certification Process
\end{tabular}} \\
\hline $\begin{array}{l}\text { Detailed procedures of } \\
\text { registration of } \\
\text { manufacturing, import, } \\
\text { trade/sale, transport, } \\
\text { storage, disposal, etc. of } \\
\text { biofertilizers and }\end{array}$ & $\begin{array}{l}\text { Registration application for biopesticides is moved } \\
\text { through Central Insecticides Board (CIB), Ministry } \\
\text { of Agriculture }\end{array}$ \\
biopesticides & $\begin{array}{l}\text { Products registered with the Agriculture Department } \\
\text { under FCO and license is issued to manufacture, } \\
\text { trade, transport, etc. }\end{array}$ \\
\hline
\end{tabular}

S sciendo Journal of Legal Studies Volume 26 Issue 40/2020 
Arjjumend, H., Koutouki. K., (2020)

Legal barriers and quality compliance in the business of biofertilizers and biopesticides in India

\begin{tabular}{|c|c|}
\hline Questions & Responses \\
\hline & $\begin{array}{l}\text { date of application, the registration under FCO } \\
\text { consumes half a year. } \\
\text { Biofertilizers are registered at the state level. } \\
\text { Biopesticides undergo intensive registration process. } \\
\text { State Department of Agriculture handles the } \\
\text { registration of biofertilizers. At district level, the } \\
\text { District Agriculture Department issues license. } \\
\text { Manufacturing in India is relatively easy and } \\
\text { advantageous. Procedure for importing is lengthy. }\end{array}$ \\
\hline $\begin{array}{l}\text { What kind of laboratory } \\
\text { tests or efficacy tests are } \\
\text { required? }\end{array}$ & $\begin{array}{l}\text { A lot of scientific data is required to register } \\
\text { biopesticide, including data on toxicity, HPLC, } \\
\text { hortitoxicity, efficacy, bioefficacy, etc. } \\
\text { Nearly } 18 \text { months are needed to register a new } \\
\text { biopesticide. } \\
\text { Efficacy tests of biofertilizers on the crops; how } \\
\text { microbial agents boost plant growth. } \\
\text { At the time of registration, only specifications need } \\
\text { to be met. Samples are taken later for laboratory test. } \\
\text { Efficacy tests and bioassays are done for } \\
\text { biopesticides, usually at research sites of designated } \\
\text { universities. } \\
\text { Efficiency performance } \\
\text { Sieve size of molecules } \\
\text { All tests are done by large companies, but difficult } \\
\text { for small companies. }\end{array}$ \\
\hline $\begin{array}{l}\text { Documents, preparations, } \\
\text { facilities, compliances, } \\
\text { etc. required at the time } \\
\text { of applying for } \\
\text { registrations }\end{array}$ & $\begin{array}{l}\text { Applicant for registration should possess } \\
\text { qualification of agriculture } \\
\text { Application forms, certificate of origin, test reports, } \\
\text { microbiological performances, bioassays, toxicity } \\
\text { reports } \\
\text { Manufacturing process details, efficiency reports } \\
\text { Company registration, tax related registrations, } \\
\text { declarations, godown \& storage, test reports } \\
\text { Samples are tested for compliance }\end{array}$ \\
\hline $\begin{array}{l}\text { Detailed account of } \\
\text { barriers at each step of } \\
\text { the registration process }\end{array}$ & $\begin{array}{l}\text { It is hard to register new product } \\
\text { Only some biopesticides are recognized and }\end{array}$ \\
\hline
\end{tabular}


Legal barriers and quality compliance in the business of biofertilizers and biopesticides in India

\begin{tabular}{|c|c|}
\hline Questions & Responses \\
\hline & $\begin{array}{l}\text { approved } \\
\text { Registration of industrial dealer is done separately in } \\
\text { each state, which means that multiple registrations } \\
\text { are required to sell in different states } \\
\text { Retailer license is issued separately in different } \\
\text { states. } \\
\text { Lack of proper information and guidance. } \\
\text { Government departments do not provide help and } \\
\text { assistance. } \\
\text { Callous attitude of officers } \\
\text { No cooperation by officers. Least cooperation. } \\
\text { No synchronized system of facilitation } \\
\text { Lengthy and time taking procedures } \\
\text { Poor departmental coordination - no fixed } \\
\text { responsibility } \\
\text { No clarity in procedures and types of documents } \\
\text { All information is not shared at a time by the officers } \\
\text { Standards are hard to comply with } \\
\text { Poor competence of the officers } \\
\text { Lack of legal knowledge }\end{array}$ \\
\hline $\begin{array}{lr}\text { How are } & \text { biologicals } \\
\text { treated } & \text { vis-à-vis } \\
\text { chemicals? } & \end{array}$ & $\begin{array}{l}\text { Biopesticides are registered at par the chemical } \\
\text { pesticides. Same tests are required for biopesticides } \\
\text { too. } \\
\text { Biologicals are in high demand over the chemicals. } \\
\text { Biologicals have far more advantage } \\
\text { No significant difference in treatment of the two } \\
\text { Biologicals are only the answers to modern } \\
\text { agriculture }\end{array}$ \\
\hline $\begin{array}{l}\text { Detailed analysis of costs } \\
\text { involved in all steps of } \\
\text { registrations and } \\
\text { associated preparations, } \\
\text { compliances, etc. }\end{array}$ & $\begin{array}{l}\text { About INR } 60 \text { million amount is required to register } \\
\text { a biopesticide } \\
\text { Done on government fee basis } \\
\text { INR } 100,000 \text { are spent on registering a biofertilizer. } \\
\text { For manufacturing registration, the amount is double. } \\
\text { Costly process for biopesticides. Small companies } \\
\text { cannot afford }\end{array}$ \\
\hline
\end{tabular}


Arjjumend, H., Koutouki. K., (2020)

Legal barriers and quality compliance in the business of biofertilizers and biopesticides in India

\begin{tabular}{|c|c|}
\hline Questions & Responses \\
\hline $\begin{array}{l}\text { Barriers in licensing } \\
\text { processes }\end{array}$ & $\begin{array}{l}\text { Licenses are issued } \\
\text { No problem as such } \\
\text { License or registration is not given unless applicant } \\
\text { conforms to the standards set out in Part-A of } \\
\text { Schedule-III Clause 13(1b) of FCO. } \\
\text { License is lengthy procedure } \\
\text { A lot many documents are required } \\
\text { Officers do not deliver in time } \\
\text { Technical specifications of bacteria or fungi are very } \\
\text { tough } \\
\text { Validity in one state only } \\
\text { No data exists on traded biofertilizers in different } \\
\text { states } \\
\text { Tremendous data is required for registering } \\
\text { biopesticides. }\end{array}$ \\
\hline $\begin{array}{l}\text { Difficulties in execution } \\
\text { of registration conditions } \\
\text { and license liabilities }\end{array}$ & $\begin{array}{l}\text { Immense promotion of biofertilizers is required along } \\
\text { with intensive technical backup support to be given } \\
\text { by manufacturing company to the farmers. } \\
\text { For manufacturer, } 18 \text { months period from date of } \\
\text { registration for complying with the conditions is less. } \\
\text { It shall be } 24 \text { months. Clause } 16(2) \text {. Actually, the } \\
\text { manufacturing takes longer time to come into } \\
\text { process. } \\
\text { Maintaining shelf-life period is difficult, as it's hard } \\
\text { to sell products within short time period. } \\
\text { It is difficult to call back the unused product at the } \\
\text { end of the wholesaler or retailer if the expiry date } \\
\text { passes } \\
\text { Microbiological viability of bacteria } \\
\text { Maintenance of effectiveness of products }\end{array}$ \\
\hline \multicolumn{2}{|c|}{ Effectiveness of Quality Monitoring (Biofertilizers) } \\
\hline $\begin{array}{l}\text { Do you perform quality } \\
\text { monitoring of the } \\
\text { biofertilizers that you } \\
\text { manufacture? }\end{array}$ & $\begin{array}{l}\text { Analysis is done in laboratory. No tests in field. } \\
\text { Yes, in manufacturing unit. } \\
\text { Big companies have well-equipped laboratories }\end{array}$ \\
\hline $\begin{array}{l}\text { Mechanism and methods } \\
\text { of your quality }\end{array}$ & Field trials of products are conducted on crops, \\
\hline
\end{tabular}


Arjjumend, H., Koutouki. K., (2020)

Legal barriers and quality compliance in the business of biofertilizers and biopesticides in India

\begin{tabular}{|l|l|}
\hline \multicolumn{1}{|c|}{ Questions } & \multicolumn{1}{c|}{ Responses } \\
\hline monitoring & $\begin{array}{l}\text { horticulture, forestry plantations } \\
\text { Soil testing laboratory gives support to farmers } \\
\text { Maintenance of specific standards } \\
\text { Packing and packaging as per standards } \\
\text { Information on packs should not be misleading } \\
\text { During manufacturing } \\
\text { Before the release of the product } \\
\text { Experimental testing on farmers lands } \\
\text { Experimentation in lab } \\
\text { Farmers' feedback }\end{array}$ \\
\hline $\begin{array}{l}\text { How often is this quality } \\
\text { monitoring? Cycle }\end{array}$ & $\begin{array}{l}\text { Regular trials } \\
\text { No set patterns } \\
\text { Quality needs to be maintained in manufacturing } \\
\text { plant and at various stages of the supply chain. } \\
\text { In factory, it is regular and prompt. On farmers' } \\
\text { lands, it is only experimental. } \\
\text { Periodic. Sor some strains, it is annual. }\end{array}$ \\
\hline $\begin{array}{l}\text { What exactly do you } \\
\text { monitor to know the } \\
\text { quality of biofertilizer(s) } \\
\text { made by you? }\end{array}$ & $\begin{array}{l}\text { It depends on the type of biofertilizer. In all } \\
\text { conditions, standard specifications have to be met. } \\
\text { Leaf index, yield } \\
\text { Specimens are verified for quality control. } \\
\text { CFU Count, bacterial activity, shelf life, moisture, } \\
\text { colony formation } \\
\text { Performance on plan growth } \\
\text { Agronomic attributes of crops, such as height, } \\
\text { biomass, length, grain size, yield, etc. } \\
\text { Effectiveness of biofertilizers } \\
\text { Whatent testing of } \\
\text { Monitoring as per specifications }\end{array}$ \\
\hline $\begin{array}{l}\text { During field tests, what } \\
\text { on yiects did you observe vigor, growth, }\end{array}$ & $\begin{array}{l}\text { No } \\
\text { Data not shared }\end{array}$ \\
\hline
\end{tabular}

sciendo Journal of Legal Studies Volume 26 Issue 40/2020 
Arjjumend, H., Koutouki. K., (2020)

"Vasile Goldiș" Western University of Arad

Legal barriers and quality compliance in the business of biofertilizers and biopesticides in India

\begin{tabular}{|c|c|}
\hline Questions & Responses \\
\hline $\begin{array}{l}\text { taste, color, grain/fruit } \\
\text { size, etc. of the plants on } \\
\text { which your } \\
\text { biofertilizer(s) applied? }\end{array}$ & In some crops, a $15-18 \%$ increase \\
\hline $\begin{array}{l}\text { How do you monitor and } \\
\text { measure the comparative } \\
\text { crop productivities } \\
\text { accruing after usage of } \\
\text { your biofertilizer by } \\
\text { farmers? }\end{array}$ & $\begin{array}{l}\text { Measurement of productivities is difficult } \\
\text { No comparative monitoring } \\
\text { By establishing control trials and comparing with } \\
\text { treated ones. }\end{array}$ \\
\hline $\begin{array}{l}\text { How and how often do } \\
\text { you monitor and measure } \\
\text { the biosafety of } \\
\text { biofertilizers that you } \\
\text { manufacture? }\end{array}$ & $\begin{array}{l}\text { Biosafety may not be an issue for biofertilizers } \\
\text { No biosafety issue } \\
\text { As such no biosafety issue. }\end{array}$ \\
\hline $\begin{array}{l}\text { Can you explain the } \\
\text { ecological footprints of } \\
\text { biofertilizers that you } \\
\text { manufacture? }\end{array}$ & $\begin{array}{l}\text { Each product has an ecological footprint. It is well } \\
\text { documented. } \\
\text { Different for each microbe. Protocol varies } \\
\text { Repair and revitalize agroecology } \\
\text { Rejuvenation of soil microflora and microfauna } \\
\text { Soil health revived }\end{array}$ \\
\hline $\begin{array}{l}\text { How do you assure the } \\
\text { designated shelf life of } \\
\text { your biofertilizer } \\
\text { products? }\end{array}$ & $\begin{array}{l}\text { Quick supply to government outlets } \\
\text { No issue regarding shelf life } \\
\text { It is quite difficult. Constant experimentation is } \\
\text { required. }\end{array}$ \\
\hline $\begin{array}{l}\text { In what way do you } \\
\text { assure that biofertilizers } \\
\text { have no risks, toxicity or } \\
\text { hazards? }\end{array}$ & $\begin{array}{l}\text { They address target plants } \\
\text { Bacteria boost N, P, K, Mg, Zn. They do not cause } \\
\text { toxins. } \\
\text { No risks } \\
\text { Biologically safe } \\
\text { Minimum risks }\end{array}$ \\
\hline \multicolumn{2}{|c|}{ Effectiveness of Quality Monitoring (Biopesticides) } \\
\hline $\begin{array}{l}\text { Do you perform quality } \\
\text { monitoring of the } \\
\text { biopesticides that you } \\
\text { manufacture? }\end{array}$ & $\begin{array}{l}\text { Entire assessment is done at the time of registration } \\
\text { process. Central Insecticide Laboratory in Delhi } \\
\text { conducts all tests. This lab is established by } \\
\text { government under Section } 16 \text { of Insecticides Act } \\
1968 \text {. }\end{array}$ \\
\hline
\end{tabular}


Arjjumend, H., Koutouki. K., (2020)

Legal barriers and quality compliance in the business of biofertilizers and biopesticides in India

\begin{tabular}{|l|l|}
\hline \multicolumn{1}{|c|}{ Questions } \\
\hline $\begin{array}{l}\text { Mechanism and methods } \\
\text { of your quality } \\
\text { monitoring }\end{array}$ & No response \\
\hline $\begin{array}{l}\text { How often is this quality } \\
\text { monitoring? Cycle }\end{array}$ & No response \\
\hline $\begin{array}{l}\text { What exactly do you } \\
\text { monitor to know quality } \\
\text { of biopesticide(s) made } \\
\text { by you? }\end{array}$ & No response \\
\hline $\begin{array}{l}\text { Do you have any protocol } \\
\text { for field testing of } \\
\text { different biopesticides? } \\
\text { What is it? }\end{array}$ & No response \\
\hline $\begin{array}{l}\text { Where have you } \\
\text { conducted field tests, and } \\
\text { how? Any documented } \\
\text { results? }\end{array}$ & CIB during the registration process. \\
\hline $\begin{array}{l}\text { During field tests, what } \\
\text { effects did you observe } \\
\text { on } \\
\text { pathogens/pest/insect/wee } \\
\text { d/ nematodes control or } \\
\text { elimination, yield, } \\
\text { growth, grain/fruit size, } \\
\text { etc. of the plants on } \\
\text { which your } \\
\text { biopesticide(s) applied? }\end{array}$ & \\
\hline $\begin{array}{l}\text { How do you monitor and } \\
\text { measure the comparative } \\
\text { crop productivities } \\
\text { accruing after usage of } \\
\text { your biopesticides by } \\
\text { farmers? }\end{array}$ & Data was not shared \\
\hline $\begin{array}{l}\text { How and how often do } \\
\text { you monitor and measure } \\
\text { the biosafety of } \\
\text { biopesticides that you } \\
\text { manufacture? }\end{array}$ & \\
\hline
\end{tabular}

sciendo Journal of Legal Studies Volume 26 Issue 40/2020 
Arjjumend, H., Koutouki. K., (2020)

Legal barriers and quality compliance in the business of biofertilizers and biopesticides in India

\begin{tabular}{|c|c|}
\hline Questions & Responses \\
\hline $\begin{array}{l}\text { Can you explain the } \\
\text { ecological footprints of } \\
\text { biopesticides that you } \\
\text { manufacture? }\end{array}$ & No response \\
\hline $\begin{array}{l}\text { How do you assure the } \\
\text { designated shelf life of } \\
\text { your biopesticide } \\
\text { products? }\end{array}$ & $\begin{array}{l}\text { As the shelf life of biopesticides is short, it is hard to } \\
\text { maintain shelf life of products. Then, manufacturing } \\
\text { and selling of products are strategically planned and } \\
\text { executed in a way to capture shelf life limits. }\end{array}$ \\
\hline $\begin{array}{l}\text { In what way do you } \\
\text { assure that biopesticides } \\
\text { have no risks, toxicity or } \\
\text { hazard? }\end{array}$ & $\begin{array}{l}\text { Biopesticides are safer as they are biological } \\
\text { material. CIB also ensures that there is no biological } \\
\text { risk or toxicity being created by the product for soil, } \\
\text { plants or other organisms. }\end{array}$ \\
\hline $\begin{array}{l}\text { How do you control and } \\
\text { monitor non-target } \\
\text { organism toxicity of the } \\
\text { biopesticides? }\end{array}$ & $\begin{array}{l}\text { In the majority of cases, biopesticides act on specific } \\
\text { organisms, e.g. fungus, insect. They mostly remain } \\
\text { active in plant body or surface until shelf life. } \\
\text { Example: "Bio-Rakshak" of Niv Shakti (for } \\
\text { Lepidopteran pests) targets the pests such as loopers, } \\
\text { caterpillars, grubs, bunch caterpillars, heliothis, moth, } \\
\text { tea twig caterpillar, etc. It does not affect any other } \\
\text { insect. }\end{array}$ \\
\hline $\begin{array}{l}\text { Is there any residue } \\
\text { contamination problem } \\
\text { (and its persistence in } \\
\text { soil) associated with } \\
\text { biopesticides that you } \\
\text { manufacture? }\end{array}$ & $\begin{array}{l}\text { Since they are non-chemicals, they do not react with } \\
\text { other substances. Therefore, residue problem does } \\
\text { not exist. }\end{array}$ \\
\hline
\end{tabular}

Source: Self-research.

Related to the difficulties in executing the registration conditions and license liabilities, the Group 1 participants said that immense promotion of biofertilizers is required, along with intensive technical backup support to be given by the manufacturing company to the farmers. For a manufacturer of pesticides, official period of 18 months period from the date of registration for complying with the conditions of registration is less (under Clause 16(2) of Insecticide Act 1968); it rather shall be 24 months or more (Table 2). For the manufacture of biopesticides, the process is even longer. Maintaining the shelf-life period is another difficult problem, as it is hard to sell products within a short period of time (Table 2). It is 
Arjjumend, H., Koutouki. K., (2020)

Legal barriers and quality compliance in the business of biofertilizers and biopesticides in India

also difficult to recall the unused product from the wholesaler dealer or retailer if the expiry date has passed (Table 2).

Whether the biologicals are treated in a manner analogous to chemicals was another question answered by the participant manufacturers/suppliers (Table 2). They replied that biopesticides are subject to the same registration requirements as chemical pesticides, and are required to undergo the same tests (Table 2). Hence, no significant difference is seen in the treatment of the two distinct materials. In fact, biologicals are more advantageous than chemical pesticides and are in higher demand. So, biologicals are only answers to modern agriculture. Therefore, biologicals should be treated differently than chemicals under Indian law.

\subsection{Effectiveness of Quality Monitoring (Biofertilizers)}

Do you perform quality monitoring of the biofertilizers that you manufacture? This question was posed to manufacturers (Table 2). They replied that analysis takes place in the laboratory of the manufacturing unit and that no tests are conducted in the field. It was observed that large companies have well-equipped laboratories. The next question was related to the mechanism and methods of quality monitoring performed by the manufacturers of biofertilizers (Table 2). The participants stated that quality monitoring is performed during manufacturing and before the release of the products into the market (Table 2). Both the Group participants and Group 2 participants reported that field trials of products are conducted on food crops, horticulture, and forestry plantations, while the soil testing laboratory gives support to farmers and specific standards are maintained (Table 2). The participants affirmed that packing and packaging remain as per set standards, and information on packaging should not be misleading. Some participants reported that experimental testing is conducted on farmers' lands on an experimentation basis. Farmers also give feedback on the field performance of products when applied to crops (Table 2).

Group 1 participants also addressed the question of how often quality monitoring takes place (Table 2). They stated that there is no set pattern of quality monitoring; monitoring in the factory setting occurs regularly, while on farmers' land monitoring is only experimental (Table 2), periodic and annual for some strains. The participant manufacturers/ suppliers also stressed that quality must be maintained in the manufacturing plant and at various stages of the supply chain (Table 2).

The next question was related to what exactly is monitored in order to determine the quality of biofertilizer(s). Both Group 1 and 2 participants replied that the answer to this question depends on the type of biofertilizer. Irrespective of the type of biofertilizer, standard specifications as set under FCO must be met. Leaf index, 
Arjjumend, H., Koutouki. K., (2020)

Legal barriers and quality compliance in the business of biofertilizers and biopesticides in India

yield, CFU count, bacterial activity, shelf life, moisture, colony formation, effect on plan growth, and agronomic attributes of crops such as height, biomass, length, grain size, and yield are measured for quality control and monitoring (Table 2). The participant manufacturers/suppliers have no protocol for the field testing of different biofertilizers (Table 2) on such parameters.

Next question was asked, "during field tests, what effects the manufacturers / suppliers had observed on yield, vigor, growth, taste, color, grain / fruit size, etc. of the plants on which they applied biofertilizer(s). The Group 1 participants replied that they observed on average a $10 \%$ increase in yield and other qualitative attributes of crops. In some crops, as much as a $15-18 \%$ increase was observed (Table 2). The participants were also asked the question, "how do you monitor and measure the comparative crop productivities accruing after usage of your biofertilizer by farmers?" Some of the participants replied that measurement of productivity is difficult and hence no comparative monitoring is done (Table 2). Some participants said that comparative productivities are measured by establishing control trials and comparing with treated crops (Table 2).

The Group 1 participants responded on how and how often they monitor and measure the biosafety of the biofertilizers that they manufacture. They stated that biosafety is not an issue for biofertilizers and thus no biosafety test is required (Table 2). Assuring that biofertilizers have no risks, toxicity or hazard, the participant manufacturers/suppliers said that biofertilizers address target plants only. Moreover, bacteria boost N, P, K, Mg, Zn and micronutrients. They do not produce toxins in soil having no risk and biological safety (Table 2). Regarding the ecological footprints of the biofertilizers that they are supposed to measure, the participant manufacturers/suppliers stated that each product (microbe) has an ecological footprint, which is well documented apart from how repair and revitalization of agroecology and rejuvenation of soil microflora and microfauna take place in the soil (Table 2). To the question "how do you assure the designated shelf life of your biofertilizer products?", participant manufacturers/suppliers gave three different answers. First, [some participants stated that] the products are supplied within the expiry limit of the shelf life. Second, [some participants stated that] there was no issue regarding shelf life. Third, [some participants stated that] it is quite difficult to sell the products within shelf life period (Table 2).

\subsection{Effectiveness of Quality Monitoring (Biopesticides)}

The surveyed manufacturers/suppliers also responded to the question of quality monitoring for biopesticides (Table 2). With respect to field tests, the participants stated that the entire assessment, including field tests, is completed at the time of the registration process. All tests are conducted by the Central Insecticide 
Arjjumend, H., Koutouki. K., (2020)

Legal barriers and quality compliance in the business of biofertilizers and biopesticides in India

Laboratory, established by the government under Section 16 of the Insecticides Act 1968 (Table 2).

Many questions concerning quality monitoring were not answered by the participants. Such questions include: (1) Mechanism and methods of quality monitoring; (2) How often is this quality monitoring conducted? (3) What exactly do you monitor to know the quality of the biopesticide(s) made by you? (4) Do you have any protocol for field testing of different biopesticides? What is it? (5) How do you monitor and measure the comparative crop productivities accruing after usage of your biopesticides by farmers? (6) Can you explain the ecological footprints of the biopesticides that you manufacture?

With respect to the question, "during field tests, what effects did you observe on pathogens/pests/insects/weeds/nematodes control or elimination, yield, growth, grain/fruit size, etc. of the plants on which your biopesticide(s) applied?", no data was shared by the participants (Table 2). Similarly, none of the participants monitor or measure the biosafety of the biopesticides that they manufacture (Table 2). Concerning the designated shelf life of biopesticide products, participant manufacturers/suppliers reported that it is difficult to maintain the shelf life of products. Hence, the manufacturing and selling of products must be strategically planned and executed in a way that accounts for shelf life limitations (Table 2). Regarding the risks, toxicity or hazards caused by biopesticides, the participants stated that biopesticides are safer than chemical pesticides, as they are biological material. As stated by government officers, the Central Insecticide Board also ensures that these products create no biological risk or toxicity for soil, plants or other organisms.

"How do you control and monitor non-target organism toxicity of the biopesticides?" This question was answered by the participant manufacturers / suppliers (Table 2). They stated that in the majority of cases, biopesticides act on specific organisms, such as fungi or insects. They mostly remain active in the plant's body or on its surface until the end of the product's shelf life. For example, the product 'Bio-Rakshak', produced by Nivshakti Bioenergy Pvt. Ltd. (for Lepidopteran pests) targets pests such as loopers, caterpillars, grubs, bunch caterpillars, heliothis, moths, and tea twig caterpillars. It does not affect any other insect (Table 2). Addressing the issue of residue contamination and persistence in soil, the participants stated that biopesticides are non-chemicals and do not react with other substances. As a result, no residue problem exists (Table 2).

\section{Conclusions}

In India, the registration application for biopesticides is submitted to the Central Insecticides Board (CIB) at the Ministry of Agriculture and registration is 
Arjjumend, H., Koutouki. K., (2020)

Legal barriers and quality compliance in the business of biofertilizers and biopesticides in India

undertaken under the Insecticides Act 1968. Licenses to sell biopesticides are issued by the State Governments. On the other hand, biofertilizers are registered with the Agriculture Department of a State Government under the Fertilizer Control Order 1985, and licenses are issued for the manufacture, importation, trade, transport, and storage. Manufacturing biologicals in India is relatively easier and more advantageous than importation, which is a lengthy process. However, the registration of biopesticides is quite a difficult and expensive process. Registration for industrial dealer or retailer licenses is completed separately in each state, meaning that multiple registrations are required to sell in different states. Other difficulties include a lack of proper information and guidance and a lack of adequate help and assistance from government departments. The callous attitude of officers and their lack of cooperation are also common problems. Other bottlenecks include a lack of proper of facilitation, lengthy procedures, poor departmental coordination, no fixed responsibility, no clarity in procedures and types of documents required, lack of competence of the officers, lack of legal knowledge, and standards that are difficult to comply with. The cost of registration for biopesticides is an important barrier. Maintaining shelf-life period is another difficult problem, as it is hard to sell products within a short period of time. Biopesticides are registered at par with chemical pesticides. The same tests are required for biopesticides too; hence, no significant difference is seen in the treatment of the two distinct materials.

The manufacturers of biofertilizers conduct tests in the laboratories of manufacturing units, rather than in the field. Quality monitoring is also performed during the manufacturing process and before the release of the products into the market. Some manufacturers reported that experimental testing is conducted on farmers' lands on an ad hoc basis. There is no set pattern of quality monitoring, and the manufacturers/suppliers have no protocol for the field testing of different biofertilizers. Overall, quality monitoring of the products does not occur on a regular basis. Biofertilizers have no associated risks, toxicity or hazards, and do not produce toxins in the soil. For biopesticides, the entire assessment process, including field tests, occurs at the time of registration, and all tests are conducted by the Central Insecticide Laboratory. The biosafety of biopesticides is not monitored by the manufacturers. The Central Insecticide Board also ensures that the product creates no biological risk or toxicity for soil, plants or other organisms. As a result, monitoring of the products' quality - especially in the farmers' fields is extremely poor. Finally, with respect to the issue of biopesticide residue contamination and its persistence in soil, the manufacturers/suppliers stated that biopesticides are not chemicals and do not react with other substances. Therefore, the residue problem does not exist. 
Arjjumend, H., Koutouki. K., (2020)

Legal barriers and quality compliance in the business of biofertilizers and biopesticides in India

\section{Acknowledgments}

The authors thank the anonymous reviewers and editor for their valuable contribution.

\section{Funding}

This research was supported financially by Mitacs (Elevate Program) and Earth Alive Clean Technologies, Inc., Canada under grant number IT09485.

\section{Authors Contribution}

This article is written by both the co-authors. The research for the article was conducted by both the co-authors under the supervision of second author.

\section{Disclosure Statement}

The authors have not any competing financial, professional, or personal interests from other parties.

\section{References}

1. Earth Alive, (2017). Earth Alive's Commitment to Sustainable Development. Retrieved from http://earthalivect.com/about-us/sustainability/ Accessed on 18 January 2017.

2. Bhide, R., (2013). Regulatory perspective of agrochemicals in India, AgroNews, July 19, 2013. Retrieved from http://news.agropages.com/News/NewsDetail---10045.htm Accessed on 25 September 2020 .

\section{Notes}

[1] CFU (colony forming unit) count refer to the number of individual colonies of any microorganism that grow on a plate of media. This value in turn represents the number of bacteria capable of replicating as they have formed colonies on the plate. There is a CFU formula that involves sampling.

[2] High-performance liquid chromatography (HPLC) is a technique in analytical chemistry used to separate, identify, and quantify each component in a mixture. It relies on pumps to pass a pressurized liquid solvent containing the sample mixture through a column filled with a solid adsorbent material.

\section{Appendices}

Appendix 1: List of Group 1 Participants (Manufacturers and Suppliers of Biofertilizers and Biopesticides)

M.1 Sandeep Jalan, Nivshakti Bioenergy Pvt. Ltd., Kolkata (West Bengal).

M.2 Dr. M.K. Basu, Nitrofix Laboratories, Kolkata (West Bengal). 
Arjjumend, H., Koutouki. K., (2020)

Legal barriers and quality compliance in the business of biofertilizers and biopesticides in India

M.3 Dr. Abhilasha Yadav, Sushila Biofertilizer Co. Pvt. Ltd., Jaunpur (Uttar Pradesh).

M.4 Minoti Chatarjee, Lila Agrotech Pvt. Ltd., Kolkata (West Bengal).

M.5 R. Singh, MaxGrow Biotech Pvt. Ltd., Ludhiana (Punjab).

M.6 P.P. Sahni, Agricare, Ludhiana (Punjab).

M.7 Nikhil Agarwal, Evergreen Biofertilizers Pvt. Ltd., Bareilly (Uttar Pradesh).

M.8 Ajay Bishnoi, Panacea International Ltd., Gurgaon (Haryana).

\section{Appendix 2: List of Group 2 Participants (Government Officers)}

O.1 Dr. Anil Kumar Shukla, Fertilizers Division, Directorate of Agriculture, Uttarakhand Government, Dehradun (Uttarakhand).

O.2 Rajveer Singh, Assistant Plant Protection Officer, Plant Protection Division, Directorate of Agriculture, Uttarakhand Government, Dehradun (Uttarakhand).

O.3 Dr. H.B. Singh, BHU Professor of Mycology \& Plant Pathology, and Member of Central Insecticide Board, Ministry of Agriculture, Government of India, New Delhi.

O.4 S. Sashmol, Fertilizer Section, Agriculture Department, Government of West Bengal, Kolkata (West Bengal).

O.5 Niranjan Lal, Director (PSU), Ministry of Chemicals and Fertilizers, Government of India, New Delhi.

O.6 Harvinder Singh, Director (M), Ministry of Chemicals and Fertilizers, Government of India, New Delhi.

O.7 Kuldeep Gautam, Joint Director - Soil Conservation, Department of Agriculture and Farmers' Welfare, Government of Haryana, Chandigarh.

O.8 Amar Chandra, Section Officer, State Agriculture Directorate, Lucknow (Uttar Pradesh).

\section{Appendix 3: Questions for Government Officers}

Documentation and Analysis of Microbial Product Registration Procedures:

- Acquisition and collection of documents concerning the registration process of biofertilizers and biopesticides.

- Review and analysis of registration processes.

- Earmarking of grey areas where further investigations are needed.

- Analysis of dispute cases.

Assessment of Effectiveness of Quality Monitoring:

- Effectiveness of Quality Monitoring (on parameters: field testing; crop productivity; growth boosting; pathogen/pest control; non-target organism toxicity; ecological footprint; biosafety; shelf-life; etc.). 
Arjjumend, H., Koutouki. K., (2020)

Legal barriers and quality compliance in the business of biofertilizers and biopesticides in India

- Which biofertilizers do you monitor? Manufactured or supplied by which company?

- Do you perform quality monitoring of biofertilizers? Where: at manufacturer end, at supplier end or at user (farmer) end?

- Mechanism and methods of your quality monitoring at different ends (manufacturer end, supplier end or farmer end).

- How often is this quality monitoring? Cycle

- What exactly do you monitor to know quality of biofertilizer(s) at different ends (manufacturer end, supplier end or farmer end)?

- How do you monitor the (comparative) crop productivities accruing after usage of your biofertilizer by farmers?

- How and how often do you monitor the biosafety of biofertilizers?

- Can you explain the ecological footprints of biofertilizers that you monitor?

- In what way do you ensure that biofertilizers have no risks, toxicity or hazard?

- Which biopesticides do you monitor? Manufactured or supplied by which company?

- Do you perform quality monitoring of biopesticides? Where: at manufacturer end, at supplier end or at user (farmer) end?

- Mechanism and methods of your quality monitoring (manufacturer end, supplier end or farmer end).

- How often is this quality monitoring? Cycle

- What exactly do you monitor to know quality of biopesticide(s) at different ends (manufacturer end, supplier end or farmer end)?

- How do you monitor the (comparative) crop productivities accruing after usage of your biopesticides by farmers?

- How and how often do you monitor and measure the biosafety of biopesticides?

- Can you explain the ecological footprints of biopesticides that you monitor?

- In what way do you ensure that biopesticides have no risks, toxicity or hazard?

- How do you control and monitor non-target organism toxicity of the biopesticides?

Is there any residue contamination problem (and its persistence in soil) associated with biopesticides that you monitor? 